\title{
Synthesis of thiophenophanes with ethyne and ethene spacers
}

\author{
Perumal Rajakumar* and Kathiresan Visalakshi \\ Department of Organic Chemistry, University of Madras, Guindy Campus, Chennai - 600025 \\ India \\ E-mail: perumalrajakumar@gmail.com
}

\begin{abstract}
Synthesis of thiophenophanes with ethyne and ethene spacers has been achieved by $O$-alkylation, Glaser-Eglinton and McMurry coupling techniques.
\end{abstract}

Keywords: Electron rich cyclophanes, Glaser-Eglinton coupling, Sonogashira coupling, stilbenophanes

\section{Introduction}

Remarkable advances have been made in the area of cyclophanes having acetylenic linkages in recent decades. The ability of the alkyne unit(s) in generating the cyclophane cavity with shape persistence $^{1}$ has often reflected its ability to complex metal ions or organic molecules, ${ }^{2}$ or to selfaggregate in some cases. ${ }^{3,4}$ The advantage of using acetylene linkage is the linearity of the ethynic bond, which turns the molecule more rigid and creates non-collapsible cavity. ${ }^{5,6}$ Further the molecules will possess molecular co-planarity due to the presence of $s p$ hybridised carbon atoms. The cavity size of a macrocycle can be altered by increasing or decreasing the number of acetylene linkages in the molecule. ${ }^{7}$ Owing to the well-ordered structures and infinite conjugation of these macrocycles, they possess interesting optical, electronic, and magnetic properties and can be ideal materials in organic light-emitting diodes, (OLEDs), ${ }^{8}$ organic fieldeffect transistors (OFETs), ${ }^{9}$ nonlinear optics (NLOs) $)^{10}$ and organic solar cells. ${ }^{11}$ Cyclophanes with excess non-bonding electrons or dense $\pi$-electron clouds could be regarded as electron rich cyclophanes. $^{12}$ Electron rich cyclophanes like stilbenophanes ${ }^{13}$ are important class of supramolecular structures in the cyclophane family since they can undergo functional group transformations and interesting photoisomerization.

Herein we report the synthesis of thiophenophanes 1, 2, 3 and 3a with ethyne spacers and 4 with ethene spacer(Figure 1). 


\section{Results and discussion}

2,5-Bis(4-(bromomethyl)phenyl)thiophene $\mathbf{5}^{14}$ on $O$-alkylation with 2.1 equiv. of propargyl alcohol 6 in the presence of $\mathrm{NaH}$ in refluxing THF afforded 2,5-bis(4-((prop-2ynyloxy)methyl)phenyl)thiophene 7 in $63 \%$ yield. The ${ }^{1} \mathrm{H}$ NMR spectrum of 2,5-bis(4-((prop2-ynyloxy)methyl)phenyl)thiophene 7 displayed a singlet at $\delta 2.40$ corresponding to the acetylenic hydrogens. The methylene hydrogens attached to the acetylenic carbon appeared as a singlet at $\delta 4.13$ and the methylene hydrogens attached to the phenyl unit appeared as a singlet at $\delta$ 4.58. The eight hydrogens in the benzene ring appeared as an $\mathrm{AB}$ quartet at $\delta 7.41-7.61(\mathrm{~J}=$ $8.0 \mathrm{~Hz}$ ). The two hydrogens in the thiophene ring appeared as singlet at $\delta 7.29$. In the ${ }^{13} \mathrm{C}$ NMR spectrum, bispropargylated precyclophane 7 showed the $O$-methylene carbon signals at $\delta 56.2$ and 70.1 along with eight signals of carbon in the aromatic region.
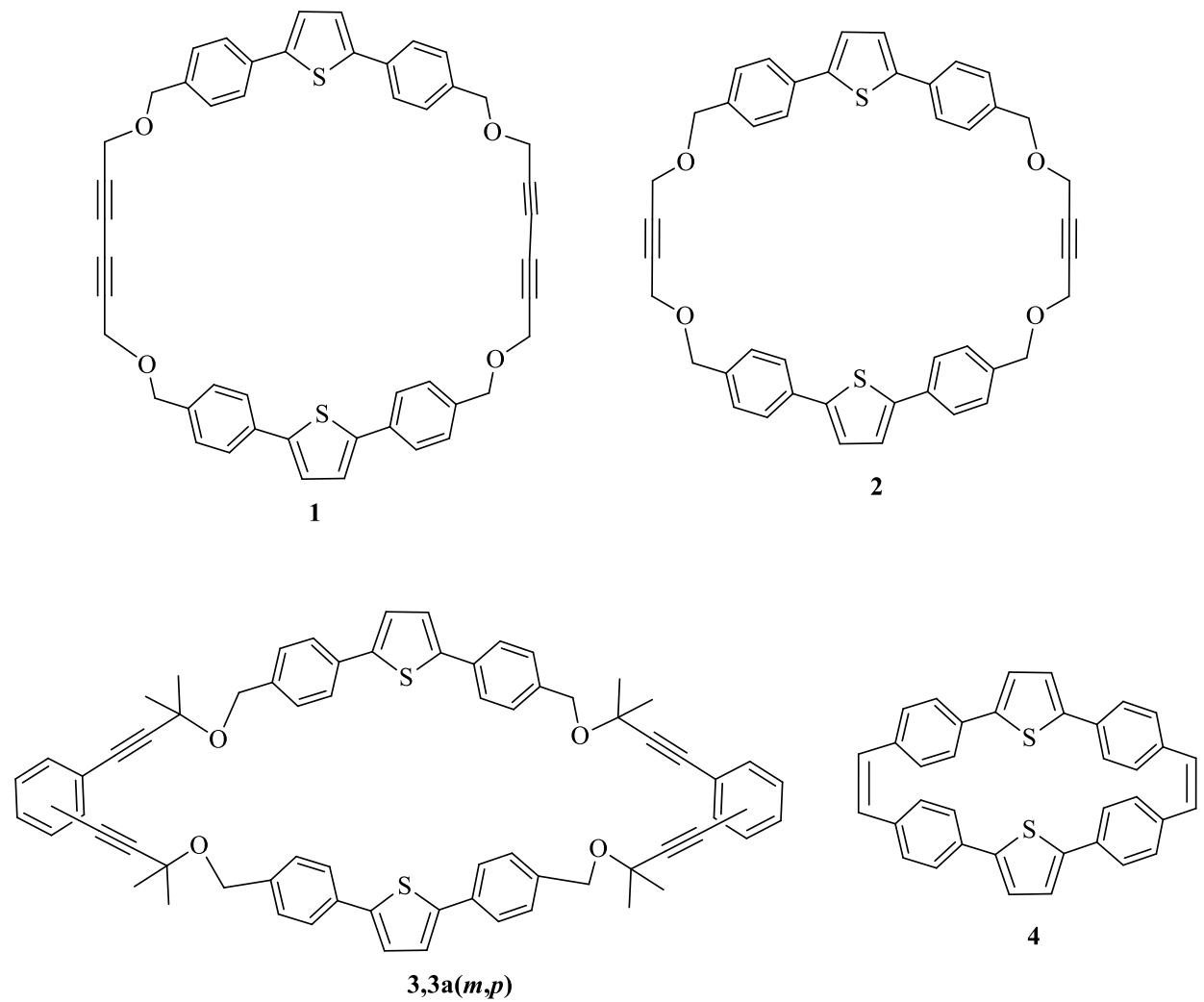

Figure 1. Structures of thiophenophanes 1, 2, 3, 3a and 4.

The bispropargylated precyclophane 7 undergoes Glaser-Eglinton coupling in the presence of $\mathrm{Cu}(\mathrm{OAc})_{2}$ in $\mathrm{CH}_{3} \mathrm{CN}$ and pyridine at $70{ }^{\circ} \mathrm{C}$ for $12 \mathrm{~h}$ to give the thiophenophane 1 in $69 \%$ yield. The ${ }^{1} \mathrm{H}$ NMR spectrum of thiophenophane 1 displayed three singlets at $\delta 4.12,4.54$ and 7.20 for eight, eight and four hydrogens corresponding to the $O$-methylene hydrogens attached to the phenyl unit, $O$-methylene hydrogens attached to the diyne unit and the hydrogen on the 
thiophenyl group respectively. The sixteen hydrogens in the benzene ring appeared as an $\mathrm{AB}$ quartet at $\delta 7.29-7.53(\mathrm{~J}=8.0 \mathrm{~Hz})$. In the ${ }^{13} \mathrm{C}$ NMR spectrum, thiophenophane 1 showed the $O$ methylene carbon signals at $\delta 56.0$ and 69.7 along with eight signals of carbon in the aromatic region. FAB-MS and elemental analysis are also in accordance with the proposed structure 1.

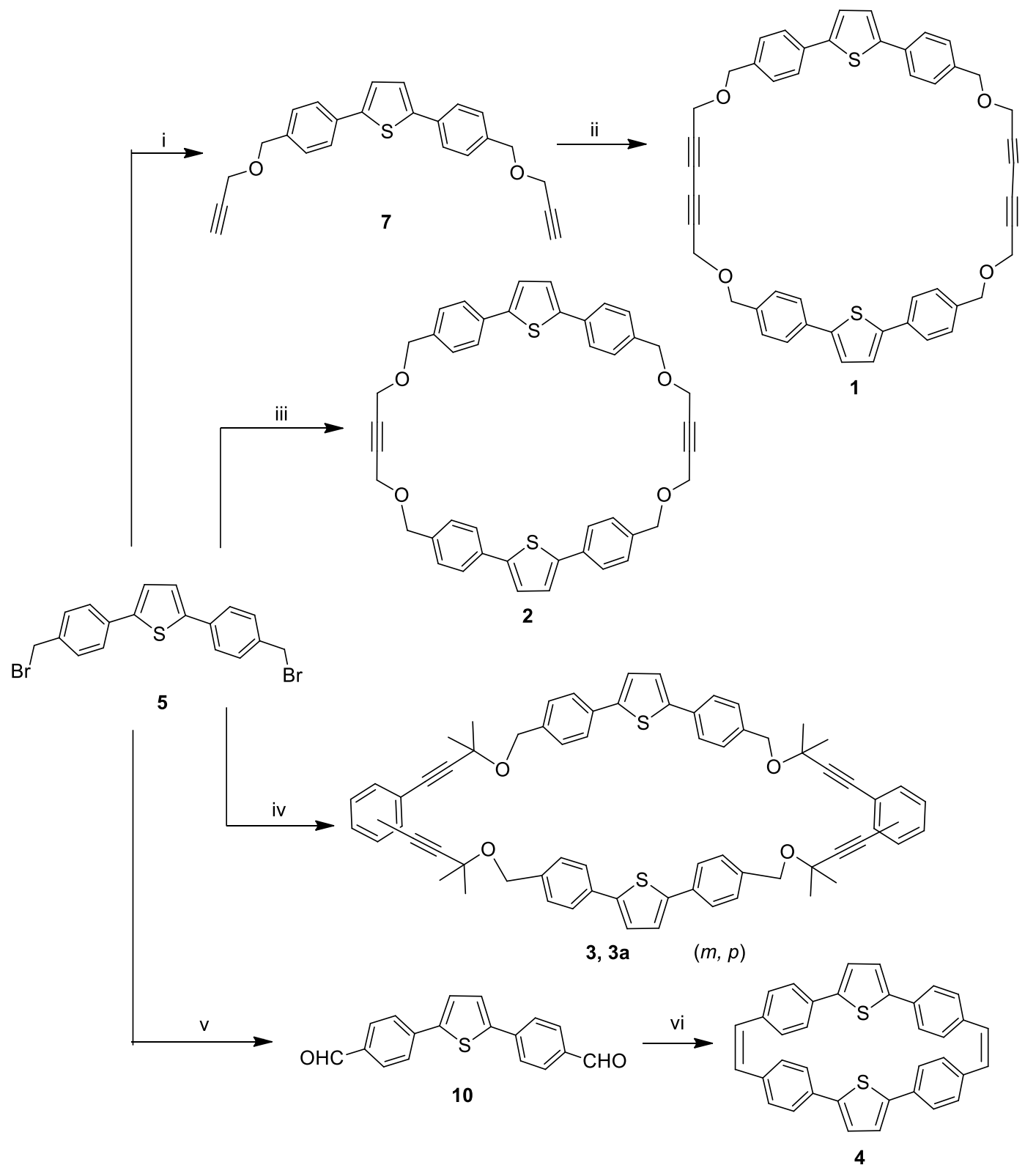

Scheme 1. Reagents and conditions: (i) 2.1 equiv. propargyl alcohol 6, NaH, THF, reflux, $12 \mathrm{~h}$ (63\%). (ii) $\mathrm{Cu}(\mathrm{OAc})_{2}, \mathrm{CH}_{3} \mathrm{CN} /$ pyridine $(3: 1), 80{ }^{\circ} \mathrm{C}, 12 \mathrm{~h}(69 \%)$. (iii) 1 equiv. but-2-yne-1,4diol 8, NaH, THF, reflux, 12 h (57\%). (iv) 1 equiv. 1,3-bis- or 1,4-bis-(3-hydroxy-3-methylbut1-ynyl)benzene 9/9a, NaH, THF, reflux, 12 h (49\%, 53\%). (v) $\mathrm{NaIO}_{4}, \mathrm{DMF}$, reflux, 1 h (69\%). (vi) 20 equiv. $\mathrm{TiCl}_{4}, 40$ equiv. $\mathrm{Zn}$, THF, pyridine, reflux, $12 \mathrm{~h}(68 \%)$. 
2,5-Bis(4-(bromomethyl)phenyl)thiophene $\mathbf{5}$ on $O$-alkylation with but-2-yne-1,4-diol $\mathbf{8}$ in the presence of $\mathrm{NaH}$ in refluxing THF afforded the thiophenophane 2 in $57 \%$ yield. The ${ }^{1} \mathrm{H}$ NMR spectrum of thiophenophane 2 displayed three singlets at $\delta 4.21,4.50$ and 7.40 for eight, eight and four hydrogens corresponding to the $O$-methylene hydrogens attached to the phenyl unit and the acetylene unit and the thiophene ring system respectively. The hydrogens in the benzene ring appeared as two doublets at $\delta 7.69-7.72(J=8.0 \mathrm{~Hz})$ and $7.81-7.83(J=8.0 \mathrm{~Hz})$ integrating for eight hydrogens each. In the ${ }^{13} \mathrm{C}$ NMR spectrum, thiophenophane 2 showed the $O$-methylene carbon signals at $\delta 58.6$ and 65.7 along with seven signals of carbon in the aromatic region. The structure of the thiophenophane $\mathbf{2}$ was also confirmed from mass and elemental analysis.

In a similar manner, thiophenophanes $\mathbf{3}$ and $\mathbf{3 a}$ were synthesized from the corresponding diol 9 and 9a obtained by the Sonogashira coupling procedure. The structure of the thiophenophanes 3 and 3a was confirmed from ${ }^{1} \mathrm{H}$ NMR, ${ }^{13} \mathrm{C}$ NMR, FAB-MS and analytical data.

2,5-Bis(4-(bromomethyl)phenyl)thiophene $\mathbf{5}$ on treatment with sodium periodate in refluxing DMF afforded 2,5-bis[4-(formyl)phenyl]thiophene $\mathbf{1 0}$ in $69 \%$ yield. The ${ }^{1} \mathrm{H}$ NMR spectrum of 2,5-bis[4-(formyl)phenyl]thiophene $\mathbf{1 0}$ displayed the aldehydic hydrogens at $\delta 9.99$, the thiophenic hydrogens at $\delta 7.46$, in addition to the other aromatic hydrogens. In the ${ }^{13} \mathrm{C} N M R$ spectrum of 2,5-bis[4-(formyl)phenyl]thiophene 10, the aldehydic carbon signal appeared at $\delta$ 191.4 , in addition to the signals of aromatic carbons.

Treatment of one equivalent of the dialdehyde $\mathbf{1 0}$ with twenty equivalents of $\mathrm{TiCl}_{4}$ and forty equivalents of $\mathrm{Zn}$ in THF under McMurry coupling conditions afforded the thiophenophane 4 in $68 \%$ yield (Scheme 1). In the ${ }^{1} \mathrm{H}$ NMR spectrum, thiophenophane 4 displayed a singlet at $\delta 7.28$ for the four thiophene hydrogens, two doublets at $\delta 7.18-7.21(J=7.5 \mathrm{~Hz})$ and $7.67-7.70(J=$ $7.2 \mathrm{~Hz}$ ) for the cis olefinic hydrogens integrating for two protons each and two more doublets at $\delta 7.38-7.40(J=7.2 \mathrm{~Hz})$ and $7.51-7.54(J=7.5 \mathrm{~Hz})$ for the ortho substituted hydrogens integrating for eight hydrogens each. The ${ }^{13} \mathrm{C}$ NMR of thiophenophane 4 displayed signals for seven carbons, which further confirmed the structure of thiophenophane 4 . The structure 4 was also confirmed from mass and elemental analysis.

Thiophenophanes with ethyne and ethene spacers have been synthesized in moderately good yield.

\section{Conclusions}

In conclusion, we have successfully synthesized electron rich thiophenophanes with ethyne and ethene spacers. The complexation of thiophenophanes with electron deficient guest molecules is under way. 


\section{Experimental Section}

General. All melting points are uncorrected. The ${ }^{1} \mathrm{H}$ and ${ }^{13} \mathrm{C}$ NMR spectra were recorded on Bruker 300 and $400 \mathrm{MHz}$ spectrometers. The chemical shifts are reported in ppm $(\delta)$ with TMS as internal standard and coupling constant $(J)$ are expressed in Hz. EI-MS spectra were recorded on JEOL DX-303 mass spectrometer. The FAB-MS spectra were recorded on JEOL SX 102/DA6000 mass spectrometer using $p$-nitrobenzyl alcohol (NBA) as matrix. Elemental analyses were performed on a Perkin-Elmer 240B elemental analyzer.

Column chromatography was performed on silica gel (ACME, 100 -200 mesh). Routine monitoring of the reaction was made using thin layer chromatography developed on glass plates coated with silica gel-G (ACME) of $25 \mathrm{~mm}$ thickness and visualized with iodine.

\section{General procedure for $\boldsymbol{O}$-alkylation using sodium hydride}

To a solution of sodium hydride $(4 \mathrm{mmol})$ in dry THF $(50 \mathrm{~mL})$, alcohol $(4 \mathrm{mmol})$ was added dropwise and stirred for $0.5 \mathrm{~h}$ at room temperature. Then the dibromide 5 (1 mmol) was added slowly to the reaction mixture and was refluxed for $12 \mathrm{~h}$. The reaction mixture was allowed to attain room temperature and then methanol $(5 \mathrm{~mL})$ was added to the reaction mixture to quench the excess sodium hydride and the reaction mixture was evaporated to dryness. The residue obtained was extracted with $\mathrm{CH}_{2} \mathrm{Cl}_{2}(2 \times 100 \mathrm{~mL})$, washed with water $(2 \times 100 \mathrm{~mL})$, brine $(100$ $\mathrm{mL}$ ) and dried over anhydrous $\mathrm{Na}_{2} \mathrm{SO}_{4}$. Evaporation of the organic layer gave a residue, which was purified by column chromatography using suitable eluent as mentioned for each compound to give the corresponding $O$-alkylated product.

2,5-Bis[4-((prop-2-ynyloxy)methyl)phenyl]thiophene (7). Following the general procedure for $O$-alkylation using sodium hydride, 2,5-bis[4-((prop-2-ynyloxy)methyl)phenyl]thiophene 7 was obtained as a yellow solid from 2,5-bis[4-(bromomethyl)phenyl]thiophene 5 (0.42 g, $1 \mathrm{mmol}$ ), propargyl alcohol $6(0.24 \mathrm{~g}, 4 \mathrm{mmol})$ and sodium hydride $(0.10 \mathrm{~g}, 4 \mathrm{mmol})$. The product was purified by column chromatography using hexane/ $\mathrm{CHCl}_{3}(3: 2)$ as eluent. Yield $63 \%$, mp $189{ }^{\circ} \mathrm{C}$; ${ }^{1} \mathrm{H}$ NMR (300 MHz, CDCl 3 ): $\delta_{\mathrm{H}} 2.40$ (s, 2H), 4.13 (s, 4H), 4.58 (s, 4H), 7.29 (s, 2H), 7.41 - 7.61 $(\mathrm{AB} q, 8 \mathrm{H}, J=8.0 \mathrm{~Hz}) .{ }^{13} \mathrm{C} \mathrm{NMR}\left(75 \mathrm{MHz}, \mathrm{CDCl}_{3}\right): \delta_{\mathrm{C}} 56.2,70.1,73.7,78.5,123.1,124.6$, 129.4, 132.8, 135.7, 142.2. MS, (EI, 70eV) m/z $372.2\left(\mathrm{M}^{+}, 100 \%\right), 373.2(\mathrm{M}+1,31.0 \%), 374.2$ (M+2, 12.6\%), 317.1 (22.4\%), 262.0 (10.1\%) ; Anal. Calcd for $\mathrm{C}_{24} \mathrm{H}_{20} \mathrm{O}_{2} \mathrm{~S}: \mathrm{C}, 77.39 ; \mathrm{H}, 5.41 \%$. Found: C, 77.28; H, 5.50\%.

\section{2(1,4),13(1,4),15(1,4),26(1,4)-Tetrabenzena-7,14,29,36-tetraoxa-1(2,5),14(2,5)-dithiophena}

cyclohexacosanaphane-6,8,19,21-tetrayne (1). A solution of bispropargylated precyclophane 7 $(0.20 \mathrm{~g}, 1 \mathrm{mmol})$ and $\mathrm{Cu}(\mathrm{OAc})_{2} . \mathrm{H}_{2} \mathrm{O}(0.50 \mathrm{~g}, 2.5 \mathrm{mmol})$ in a mixture of $\mathrm{CH}_{3} \mathrm{CN}(12 \mathrm{~mL})$ and pyridine $(3 \mathrm{~mL})$ was stirred at $70{ }^{\circ} \mathrm{C}$ for $12 \mathrm{~h}$. The reaction mixture was poured into dilute $\mathrm{HCl}$ $(250 \mathrm{~mL}, 5 \% \mathrm{HCl})$, extracted with $\mathrm{CHCl}_{3}(250 \mathrm{~mL})$, washed with water $(200 \mathrm{~mL})$, brine $(100$ $\mathrm{mL}$ ) and dried over anhydrous $\mathrm{Na}_{2} \mathrm{SO}_{4}$. The crude product obtained after the evaporation of the organic layer gave a residue, which was purified by column chromatography over $\mathrm{SiO}_{2}$ using hexane $/ \mathrm{CHCl}_{3}(3: 2)$ as an eluent to give the thiophenophane $\mathbf{1}$ as a yellow solid. Yield $69 \%$, mp 
$300{ }^{\circ} \mathrm{C} ;{ }^{1} \mathrm{H}$ NMR $\left(300 \mathrm{MHz}, \mathrm{CDCl}_{3}\right): \delta_{\mathrm{H}} 4.12(\mathrm{~s}, 8 \mathrm{H}), 4.54(\mathrm{~s}, 8 \mathrm{H}), 7.20(\mathrm{~s}, 4 \mathrm{H}), 7.29-7.53(\mathrm{AB}$ q, $16 \mathrm{H}, J=8.0 \mathrm{~Hz}) .{ }^{13} \mathrm{C} \mathrm{NMR}\left(75 \mathrm{MHz}, \mathrm{CDCl}_{3}\right): \delta_{\mathrm{C}} 56.0,69.7,70.9,76.5,123.5,125.6,129.7$, 135.2, 137.4, 143.3. MS, (FAB-MS) m/z $740\left(\mathrm{M}^{+}\right)$; Anal. Calcd for $\mathrm{C}_{48} \mathrm{H}_{36} \mathrm{O}_{4} \mathrm{~S}_{2}$ : C, 77.81; H, 4.90\%. Found: $\mathrm{C}, 77.92 ; \mathrm{H}, 4.81 \%$.

\section{2(1,4),11(1,4),13(1,4),22(1,4)-Tetrabenzena-7,12,27,32-tetraoxa-1(2,5),12(2,5)-dithiophena}

cycloeicosanaphane-6,17-diyne (2). Following the general procedure for $O$-alkylation using sodium hydride, thiophenophane $\mathbf{2}$ was obtained as a yellow solid from 2,5-bis[4(bromomethyl)phenyl]thiophene 5 (0.42 g, $1 \mathrm{mmol})$, but-2-yne-1,4-diol 8 (0.09 g, $1 \mathrm{mmol})$ and sodium hydride $(0.10 \mathrm{~g}, 4 \mathrm{mmol})$. The product was purified by column chromatography using hexane $/ \mathrm{CHCl}_{3}(2: 3)$ as eluent. Yield $57 \%$, mp $300{ }^{\circ} \mathrm{C} ;{ }^{1} \mathrm{H} \mathrm{NMR}\left(300 \mathrm{MHz}, \mathrm{CDCl}_{3}\right): \delta_{\mathrm{H}} 4.21$ (s, $8 \mathrm{H}), 4.50(\mathrm{~s}, 8 \mathrm{H}), 7.40(\mathrm{~s}, 4 \mathrm{H}), 7.69-7.72(\mathrm{~d}, 8 \mathrm{H}, J=8.0 \mathrm{~Hz}), 7.81-7.83(\mathrm{~d}, 8 \mathrm{H}, J=8.0 \mathrm{~Hz})$. ${ }^{13} \mathrm{C}$ NMR $\left(75 \mathrm{MHz}, \mathrm{CDCl}_{3}\right): \delta_{\mathrm{C}} 58.6,65.7,76.0,121.2,123.4,124.1,125.2,128.9,136.9$. MS, (EI, 70eV) m/z $692\left(\mathrm{M}^{+}, 10.8 \%\right), 428.1$ (54.4\%), 260.2 (25.1\%); Anal. Calcd for $\mathrm{C}_{44} \mathrm{H}_{36} \mathrm{O}_{4} \mathrm{~S}_{2}$ : C, $76.27 ; \mathrm{H}, 5.24 \%$. Found: C, 76.36; H, 5.13\%.

2(1,4), 8(1,3),14(1,4),16(1,4), 22(1,3),28(1,4)-Hexabenzena-5,5,11,11,19,19,25,25-octamethyl7,19,34,46-tetraoxa-1(2,5),15(2,5)-dithiophenacyclooctacosanaphane-6,9,20,23-tetrayne (3). Following the general procedure for $O$-alkylation using sodium hydride, thiophenophane $\mathbf{3}$ was obtained as a yellow solid from 2,5-bis[4-(bromomethyl)phenyl]thiophene 5 (0.50 g, $1.2 \mathrm{mmol}$ ), 1,3-bis(3-hydroxy-3-methylbut-1-ynyl)benzene 9 (0.29 g, $1.2 \mathrm{mmol})$ and sodium hydride (0.12 $\mathrm{g}, 4.7 \mathrm{mmol})$. The product was purified by column chromatography using hexane/ $\mathrm{CHCl}_{3}(2: 3)$ as eluent. Yield 49\%, mp $300{ }^{\circ} \mathrm{C} ;{ }^{1} \mathrm{H}$ NMR (300 MHz, $\left.\mathrm{CDCl}_{3}\right): \delta_{\mathrm{H}} 1.91$ (s, 24H), $5.32(\mathrm{~s}, 8 \mathrm{H}), 7.19$ $(\mathrm{s}, 4 \mathrm{H}), 7.26-7.42(\mathrm{~m}, 8 \mathrm{H}), 7.71-7.86\left(\mathrm{AB}_{\mathrm{q}}, 16 \mathrm{H}, J=8.4 \mathrm{~Hz}\right) .{ }^{13} \mathrm{C} \mathrm{NMR}\left(75 \mathrm{MHz}, \mathrm{CDCl}_{3}\right): \delta_{\mathrm{C}}$ 31.6, 63.7, 65.3, 77.3, 98.7, 121.1, 122.3, 123.1, 124.5, 124.8, 127.7, 129.4, 132.5, 135.6, 142.3. MS, (FAB-MS) m/z $1004\left(\mathrm{M}^{+}\right)$; Anal. Calcd for $\mathrm{C}_{68} \mathrm{H}_{60} \mathrm{O}_{4} \mathrm{~S}_{2}$ : C, 81.24; H, 6.02\%. Found: C, $81.15 ; \mathrm{H}, 5.91 \%$.

2(1,4), 8(1,4),14(1,4),16(1,4), 22(1,4),28(1,4)-Hexabenzena-5,5,11,11,19,19,25,25-octamethyl7,18,33,44-tetraoxa-1(2,5),15(2,5)-dithiophenacyclooctacosanaphane-6,9,20,23-tetrayne

(3a). Following the general procedure for $O$-alkylation using sodium hydride, thiophenophane 3a was obtained as a yellow solid from 2,5-bis[4-(bromomethyl)phenyl]thiophene 5 (0.50 g, 1.2 mmol), 1,4-bis(3-hydroxy-3-methylbut-1-ynyl) benzene 9a (0.29 g, $1.2 \mathrm{mmol})$ and sodium hydride $(0.12 \mathrm{~g}, 4.7 \mathrm{mmol})$. The product was purified by column chromatography using hexane/ $\mathrm{CHCl}_{3}(2: 3)$ as eluent. Yield 53\%, mp > $300{ }^{\circ} \mathrm{C} ;{ }^{1} \mathrm{H} \mathrm{NMR}\left(300 \mathrm{MHz}, \mathrm{CDCl}_{3}\right): \delta_{\mathrm{H}} 1.89$ (s, $24 \mathrm{H}), 5.29(\mathrm{~s}, 8 \mathrm{H}), 7.12(\mathrm{~s}, 4 \mathrm{H}), 7.23-7.39(\mathrm{~m}, 8 \mathrm{H}), 7.68-7.84\left(\mathrm{AB}_{\mathrm{q}}, 16 \mathrm{H}, J=8.2 \mathrm{~Hz}\right) .{ }^{13} \mathrm{C}$ NMR (75 MHz, $\left.\mathrm{CDCl}_{3}\right): \delta_{\mathrm{C}} 31.2,63.3,64.9,77.1,98.1,120.6,121.7,122.9,123.1,124.2,127.3$, 129.0, 132.1, 135.5, 142.2. MS, (FAB-MS) m/z $1004\left(\mathrm{M}^{+}\right)$; Anal. Calcd for $\mathrm{C}_{68} \mathrm{H}_{60} \mathrm{O}_{4} \mathrm{~S}_{2}$ : C, 81.24; H, 6.02\%. Found: C, 81.33; H, 6.13\%.

2,5-Bis[4-(formyl)phenyl]thiophene (10). A single-necked round bottom flask charged with 2,5-bis[4-(bromomethyl)phenyl]thiophene 5 (0.43 g, 1 mmol), $\mathrm{NaIO}_{4}(0.43 \mathrm{~g}, 2 \mathrm{mmol})$ and DMF (40 $\mathrm{mL}$ ) was kept at reflux for $1 \mathrm{~h}$. After the completion of the reaction (monitored by TLC), the reaction mixture was extracted with $\mathrm{CH}_{2} \mathrm{Cl}_{2}(2 \times 100 \mathrm{~mL})$, washed with water $(3 \times 100 \mathrm{~mL})$, brine 
(100 $\mathrm{mL}$ ) and dried over anhydrous $\mathrm{Na}_{2} \mathrm{SO}_{4}$. Evaporation of the organic layer gave a residue, which was purified by column chromatography using hexane $/ \mathrm{CHCl}_{3}(9: 1)$ as an eluent to give the corresponding 2,5-bis[4-(formyl)phenyl]thiophene 12 as a yellow solid. Yield 69\%, mp > $260{ }^{\circ} \mathrm{C}$; IR $\left(\mathrm{KBr}, v_{\max }, \mathrm{cm}^{-1}\right) 1693.6(\mathrm{C}=\mathrm{O}) .{ }^{1} \mathrm{H}$ NMR $\left(500 \mathrm{MHz}, \mathrm{CDCl}_{3}\right): \delta_{\mathrm{H}} 9.99$. (s, 2H), 7.46 (s, 2H), $7.76-7.77$ (d, 4H, $J=8.0 \mathrm{~Hz}), 7.88-7.90(\mathrm{~d}, 4 \mathrm{H}, J=8.0 \mathrm{~Hz}) .{ }^{13} \mathrm{C} \mathrm{NMR}(125 \mathrm{MHz}$, $\left.\mathrm{CDCl}_{3}\right): \delta_{\mathrm{C}} 125.9,126.4,130.6,135.4,139.5,143.9,191.4 . \mathrm{MS},(\mathrm{EI}, 70 \mathrm{eV}) \mathrm{m} / \mathrm{z} 292.2\left(\mathrm{M}^{+}\right.$, 30.2\%), 235.0 (12.0\%), 57.1.0 (100\%); Anal. Calcd for $\mathrm{C}_{18} \mathrm{H}_{12} \mathrm{O}_{2} \mathrm{~S}: \mathrm{C}, 73.95 ; \mathrm{H}, 4.14 \%$. Found: C, $74.11 ; \mathrm{H}, 4.03 \%$.

\section{$\mathbf{2}(1,4), 5(1,4), 7(1,4), 10(1,4)-T e t r a b e n z e n a-1(2,5), 6(2,5)$-dithiophenacyclodecaphane-3,8-diene}

(4). A solution of zero valent titanium prepared from $\mathrm{TiCl}_{4}(2.73 \mathrm{~g}, 14 \mathrm{mmol})$ with zinc $(1.88 \mathrm{~g}$, $28 \mathrm{mmol})$ and a few drops of pyridine $(0.5 \mathrm{~mL})$ in dry THF $(50 \mathrm{~mL})$ under nitrogen atmosphere at $0{ }^{\circ} \mathrm{C}$ was allowed to attain room temperature after $0.5 \mathrm{~h}$ and was then refluxed for $1 \mathrm{~h}$. Dialdehyde $10(0.21 \mathrm{~g}, 0.9 \mathrm{mmol})$ was added in one portion to the freshly prepared low valent titanium. After the addition, the reaction mixture was refluxed for $12 \mathrm{~h}$. The reaction mixture was cooled and then quenched with $\mathrm{K}_{2} \mathrm{CO}_{3}$ solution $(20 \mathrm{~mL}$ of $40 \% \mathrm{v} / \mathrm{v})$. The precipitated inorganic material was removed by filtration. The precipitate was thoroughly washed thrice with THF $(3 \times$ $100 \mathrm{~mL}$ ) and the combined THF extract was evaporated under reduced pressure. The residue was then dissolved in water and extracted with $\mathrm{CHCl}_{3}(200 \mathrm{~mL})$, washed with water $(2 \times 200 \mathrm{~mL})$ brine $(100 \mathrm{~mL})$ and dried over $\mathrm{Na}_{2} \mathrm{SO}_{4}$. Crude product obtained after evaporation of $\mathrm{CHCl}_{3}$, was purified by column chromatography using hexane/ $\mathrm{CHCl}_{3} \quad(4: 1)$ as an eluent to give the corresponding thiophenophane 4. Yield $68 \%$, mp $134-136{ }^{\circ} \mathrm{C} ;{ }^{1} \mathrm{H}$ NMR $\left(300 \mathrm{MHz}, \mathrm{CDCl}_{3}\right): \delta_{\mathrm{H}}$ $7.19-7.21(\mathrm{~d}, 2 \mathrm{H}, J=7.5 \mathrm{~Hz}), 7.28(\mathrm{~s}, 4 \mathrm{H}), 7.38-7.40(\mathrm{~d}, 8 \mathrm{H}, J=7.2 \mathrm{~Hz}), 7.51-7.54(\mathrm{~d}, 8 \mathrm{H}, J$ $=7.5 \mathrm{~Hz}), 7.67-7.70(\mathrm{~d}, 2 \mathrm{H}, J=7.2 \mathrm{~Hz}) .{ }^{13} \mathrm{C} \mathrm{NMR}\left(75 \mathrm{MHz}, \mathrm{CDCl}_{3}\right): \delta_{\mathrm{C}} 124.7,125.7,126.4$, 127.6, 129.7, 131.4, 141.6. MS, (EI, 70eV) m/z 520.0 (M+, 90.3\%), 521.1 (M+1, 29.0\%), 522.1 $(\mathrm{M}+2,9.6 \%), 288.1$ (22.4\%), 236.0 (95.1\%); Anal. Calcd for $\mathrm{C}_{36} \mathrm{H}_{24} \mathrm{~S}_{2}: \mathrm{C}, 83.04 ; \mathrm{H}, 4.65 \%$. Found: C, 82.97; H, 4.74\%.

\section{Acknowledgements}

The authors thank DST-FIST for providing NMR facilities to the department. KTV thank CSIR for the award of SRF.

\section{References}

1. (a) Godt, A.; Duda, S.; Unsal, O.; Thiel, J.; Härter, A.; Roos, M.; Tschierske, C.; Diele, S. Chem. Eur. J. 2002, 5094. (b) Ohkita, M.; Ando, K.; Suzuki, T.; Tsuji, T. J. Org. Chem. 2000, 65, 4385. (c) Hoger, S. J. Polym. Sci., A, Polym. Chem. 1999, 37, 2685. (d) Moore, J. S. Acc. Chem. Res. 1997, 30, 402. 
2. (a) Youngs, W. J.; Tessier, C. A.; Bradshaw, J. D. Chem. Rev. 1999, 99, 3153. (b) Yamaguchi, Y.; Kobayashi, S.; Amita, N.; Wakamiya, T.; Matusbara, Y.; Sugimoto, K.; Yoshida, Z. - I. Tetrahedron Lett. 2002, 43, 3277.

3. Bong, D. T.; Clark, T. D.; Granja, J. R.; Ghadiri, M. R. Angew. Chem. Int. Ed. 2001, 40, 988.

4. (a) Tobe, Y.; Utsumi, N.; Kawabata, K.; Nagano, A.; Adachi, K.; Araki, S.; Sonoda, M.; Hirose, K.; Naemura, K. J. Am. Chem. Soc. 2002, 124, 5350. (b) Nakamura, K.; Okubo, H.; Yamaguchi, M. Org. Lett. 2001, 3, 1097.

5. Viehe, H. G. Chemistry of Acetylene, Marcel Dekker, New York, 1969.

6. Tobe, Y.; Utsumi, N.; Kawabata, K.; Nagano, A.; Adachi, K.; Araki, S.; Sonoda, M.; Hirose, K.; Naemura, K. J. Am. Chem. Soc. 2002, 124, 5350.

7. Srinivasan, M.; Sankararaman, S.; Hopf, H.; Dix, I.; Jones, P. G. J. Org. Chem. 2001, 66, 4299.

8. (a) Brunner, K.; Dijken, A.; Borner, H.; Bastiaansen, J. J. A. M.; Kiggen, N. M. M.; Langeveld, B. M. W. J. Am. Chem. Soc. 2004, 126, 6035. (b) Li, J.; Liu, D.; Li, Y.; Lee, C.S.; Kwong, H. - L.; Lee, S. Chem. Mater. 2005, 17, 1208.

9. Zhang, Y.; Wada, T.; Sasabe, H. J. Mater. Chem. 1998, 8, 809.

10. (a) Morin, J. - F.; Drolet, N.; Tao, Y.; Leclerc, M. Chem. Mater. 2004, 16, 4619. (b) Wu, Y.; Li, Y.; Gardner, S.; Ong, B. S. J. Am. Chem. Soc. 2005, 127, 614.

11. Ooi, Z. E.; Tam, T. L.; Shin, R. Y. C.; Chen, Z. K.; Kietzke, T.; Sellinger, A.; Baumgarten, M.; Müllen, K.; de Mello, J. J. Mater. Chem. 2008, 18, 4619.

12. Hopf, H. Tetrahedron 2008, 64, 11504.

13. Rajakumar, P.; Murali, V. Tetrahedron 2004, 60, 2351.

14. Rajakumar, P.; Visalakshi, K. Supramol. Chem. 2009, 21, 674. 